Received: 14/11/2018

Revision: 21/06/2019

Accepted: 28/06/2019

OnlineFirst:03/09/2019

\title{
A Mixed-Method Study of the Epistemological Teacher-beliefs towards Educational Research in Classroom Teaching Practices
}

\section{Siti Noor Ismail}

Assoc. Prof., School of Education, Universiti Utara Malaysia, Malaysia, siti.noor@uum.edu.my

\section{Abdul Hamid Busthami Nur}

Dr., School of Education, Universiti Utara Malaysia, Malaysia, busthami@uum.edu.my

\section{Arumugam Raman}

Assoc. Prof., School of Education, Universiti Utara Malaysia, Malaysia, arumugam@uum.edu.my

\section{Yoppy Wahyu Purnomo}

Dr., Universitas Muhammadiyah Prof. DR. HAMKA, Jakarta, Indonesia, yoppy.w.purnomo@uhamka.ac.id

This study was conducted to identify whether the epistemological teacher-beliefs contributes towards the educational research practice in the classroom. This study involved 500 secondary schools teachers in the East Peninsular Malaysia whereby a mixed-method approach using a standard questionnaire and interview was used. In this study, a questionnaire on Teachers' Perception towards Epistemology (Knowledge) was adapted from Hofer \& Pintrich (2002), and to measure Teachers' Perception towards Educational Research, researchers have adapted the questionnaires from Broekkamp \& Van Hout-Wolters (2007). The findings from Pearson Correlations showed that there is a weak positive relationship but significant $(\mathrm{r}=.26, \mathrm{p}=.00)$, whereas multiple regression analysis showed that epistemological teacher-beliefs $(\beta=.26, p<.05)$ is a predictor for educational research. Furthermore, interview findings showed that the element of epistemological teacher-beliefs understanding and the support of school administrators is a contributing factor to the success of educational research in schools.It was recommended among others that the school leaders should continue to strengthen educational research practices among teachers as an effort to improve teaching quality and the effectiveness of the schools.

Keywords: epistemological, teacher-beliefs, educational research, teaching practices, teaching quality, secondary schools

Citation: Ismail, S. N., Busthami Nur, A. H., Raman, A., \& Purnomo, Y. W. (2019). A Mixed-Method Study of the Epistemological Teacher-beliefs towards Educational Research in Classroom Teaching Practices. International Journal of Instruction, 12(3), 393-406. https://doi.org/10.29333/iji.2019.12426a 


\section{INTRODUCTION}

In the past few years a great deal of discussion has taken place in the UK about the importance of educational research, particularly its value to policy makers and its usefulness to teachers. One of the key issues in this debate has been the extent to which the purpose of carrying out research in education should be chiefly directed towards school improvement in general and, in particular, towards facilitating effective classroom practice (Galton, 2000). Much of the research on the usefulness of educational research for teachers has emerged from abroad, including Canada (Cooper, 2010; Lysenko, Abrami, \& Bernard, 2011), Great Britain (Cordingley, 2009), Turkey (Beycioglu \& Ozer, 2008), and the Netherlands (Bronkhorst, Meijer, Koster, \& Vermunt, 2011). Some researchers note that educational researchers may not be adequately prepared to disseminate research to practitioners in useful ways (Schoenfeld, 2009). But it is not readily understood whether there are more fundamental criticisms to the nature of the research being produced. For teachers to make effective use of new knowledge being developed by the field, they must be able to identify and access highquality research.

According to Hargreaves (1996), teaching is a professional activity that should consider new research findings and take into account students' skills and competencies required in a fast-changing world. Teachers who hold beliefs that educational research is an important source for improving their practices tend to make effort in implementing it in classrooms. It has been clarified by several researchers (Pajares, 1992; Everton, Galton, \& Pell, 2000; Groth \& Bergner, 2007; Purnomo, Suryadi, \& Darwis, 2016, Morales et. al., 2016) that belief has a role to direct a person to make decisions and to behave. Teachers' beliefs, practices and attitudes are important for understanding and improving educational processes. They are closely linked to teachers' strategies for coping with challenges in their daily professional life and to their general well-being; they shape students' learning environment and influence student motivation and achievement.

However, in most cases teaching practices are not in line with research (Broekkamp \& Van Hout-Wolters, 2007; Purnomo et. al., 2016; Vanderlinde \& Van Braak, 2010). There is a gap between findings from educational research and classrooms practices. Besides, Hemsley-Brown and Sharp's (2003) did a cross-national review of research on this topic, revealed that there were indeed barriers to teachers' use of educational research, including a lack of access to academic journals, the daunting amount of research, jargon and overly theoretical orientations, and distrust of the findings. Further, the development in educational research should influence and direct teachers for improving their practices in classroom. Thus, this study was carried out to fill the gap that existed in educational research as described above and further identify whether the epistemological teacher-beliefs on educational research influences their teaching practices in the classroom.

\section{THEORETICAL BACKGROUND}

\section{The Theory and Concept of Epistemological Teacher-Beliefs}

Epistemology refers to the question of how a thing is accepted as knowledge. According to Hofer and Pintrich (1997), epistemology is a branch of 
philosophy concerned with the nature and justification of knowledge. Epistemological beliefs are those personally held beliefs about the nature and structure of knowing (Brownlee \& Joanne, 2004). In particular, the body of literature related to teacherbeliefs about knowing and learning, otherwise known as epistemological beliefs (Beers, 1984; Hofer \& Pintrich, 1997; Schommer, 1993a, 1993b). In the context of this study, epistemological beliefs refer holistically to personally held beliefs about what knowledge is, how it can be gained, its degree of certainty, and the limits and criteria for determining knowledge (Perry, 1981).

The importance of teacher-beliefs within teacher education rests with the constructivist's conception of learning; that beliefs are thought of as critical in terms of what and how the student teacher makes sense of their learning in the teacher education program. Smylie (1988) stated that "teacher's perceptions and beliefs are the most significant predictors of individual change". With this in mind, a growing body of research is indicating that teacher educators need to focus on teacher-beliefs as a way to facilitate effective learning in tertiary education (Fang, 1996; Richardson, Anders, Tidwell \& Lloyd, 1991) and may provide valuable insights into how to improve teaching and learning in higher education (Beers, 1984; Hofer \& Pintrich, 1997; Schommer, 1993a, 1993b).

Previous research suggests that teachers possess limited or narrow beliefs about teaching (Wilke, 2004). Many appear to hold a simplistic view of the profession (Whitbeck, 2000). As a result, teacher education may find itself competing with previously established beliefs that play an active role in the acquisition of new knowledge (FeimanNemser et al., 1989; Gunstone, 1989; Mertz, 1991; McLean, 1999). Individuals' prior educational beliefs about teaching are augmented by the stability of such beliefs and their resistance to change (Joram \& Gabriele, 1998; Kagan, 1992; Marso \& Pigge, 1989; Mertz, 1991), resulting in important implications in teachers training. Although some researchers have shown that some individuals change their beliefs in certain situations, personal knowledge or belief is often maintained even in the face of contradictory evidence that can be verified scientifically (Wilke, 2004).

\section{The Theory and Concept of Educational Research for Classroom Practice}

The main factor in student academic achievement is the learning and teaching process that takes place in the classroom, whether effective or not. The effectiveness of the learning and teaching process depends on the competence and creative ability of the teacher, their ability to incorporate the practical classroom theory and experience. Only theories will not produce effective teaching. Similarly with practice, practice without a strong theory also does not yield excellent results. On the other hand, the combination of both theoretical and the practice of the new teacher is to produce excellent results as desired. Good teacher practice is where teachers have the knowledge of subject matter, and their ability to implement new strategies, to develop effective performance tasks, to plan appropriate assessment tools, and to address different student learning styles (Stafford, 2006). To get all of these elements, teachers should implement educational research to identify the need for effective teaching in the classroom. The findings of the study by Galton (2000) who have conducted a study entitled "Integrating Theory and Practice: Teachers' Perspectives on Educational Research" have shown that there are six 
(6) educational issues most frequently discussed by teachers for further study. The issues are:

- Comparison of different teaching strategies which was chosen by $61 \%$ of teachers.

- Models of effective classroom teacher behaviour which was selected by $57 \%$ of teachers.

- Strategies for teaching different ability groups effectively which was mentioned by $54 \%$ of the teachers.

- Improving motivation and tackling disengagement selected by $50 \%$ of teachers.

- Developing creative thinking in pupils mentioned by $45 \%$ of teachers.

- Effective whole class teaching which was selected by $40 \%$ of teachers.

However, there were different priorities when teachers were asked to identify their three most important issues for further research. In analysing the degree of importance attached to a particular issue first choices were weighted three times as important as third choices and second choices were weighted two times as important. The need to improve motivation and tackle pupil disengagement was regarded as almost twice as important as any other issue when this weighting system was employed. This was then followed by comparisons of different teaching strategies and strategies for teaching different ability groups effectively. Not included in the six most frequently mentioned topics but regarded as the fourth most important issue was the link between information and communication technology and pedagogy (Galton, 2000).

For teachers to use evidence to improve teaching and learning in their classrooms they need information about what their students know and can do, evidence about their own practice and its impact on students, and knowledge of the research evidence and that from other established sources to give direction for improvements to practice (Earl \& Timperley, 2008). Research has also identified the key characteristics of effective teaching including: pedagogical content knowledge; curriculum coverage; the judicious mixture of whole class teaching, group work and personalized learning; continuous and comprehensive assessment of pupil learning, combined with feedback about what has been achieved and what needs to be learned next; and promoting and extending metacognitive skills (OECD, 2012; Hopkins, 2013). It can be inferred that possessing a wide range of instructional techniques and assessment strategies, together with updating one's subject knowledge, requires teachers to have a good knowledge of the research literature on teaching and learning. Indeed, a number of studies (Earl \& Timperley, 2008; Earl \& Katz, 2006) suggest that the use of research is a characteristic of high-quality teaching.

\section{Model of Learning}

This study was conducted in accordance with the Relational model of teaching modelled by Brownlee (2004) which was adapted from Biggs (1993). This model is called 3P Model of Learning by Brownlee (2004). The following Figure is a summary of relational teaching that has emerged in this study and is based on the 3P Model of Learning (Biggs, 1993). In this model of teaching, the 3 "P's" are based on the presage, 
process and product aspects of teaching rather than learning as originally described by Biggs' model.

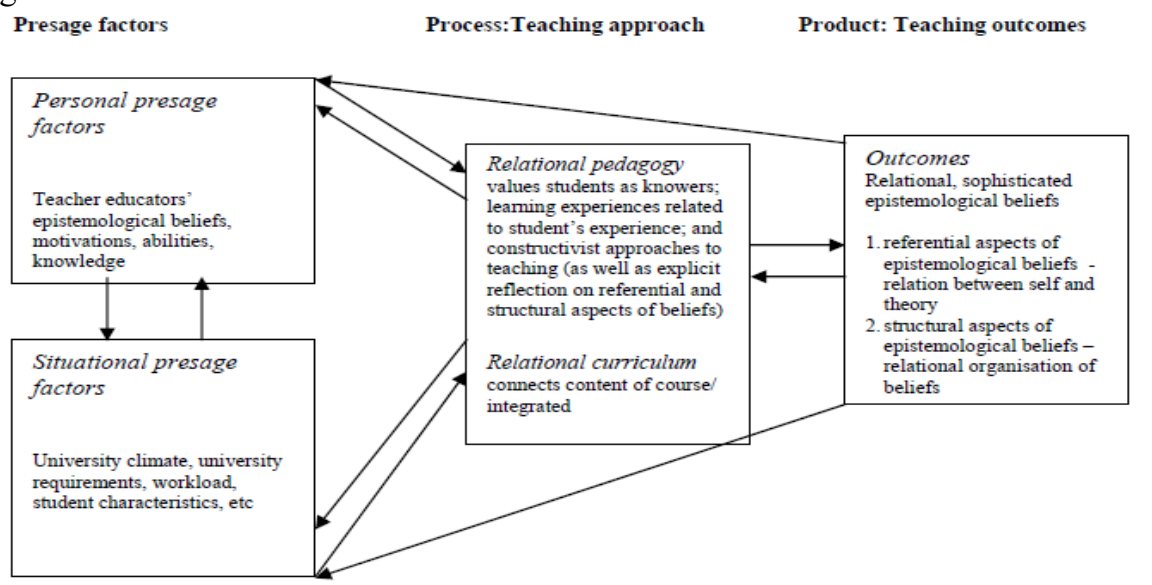

Figure1

A Relational Model of Teaching, 3P Model of Learning (Brownlee, 2004)

In Figure 1, teachers come to a teaching/learning context with their personal epistemological beliefs, abilities, and knowledge, which represent personal presage factors. Such personal factors interact with the teaching context (situational presage factors) to produce an approach to teaching. This suggests that teachers' personal and situational presage factors will influence the use of relational pedagogy (and relational curriculum) as an approach to teaching and ultimately teaching outcomes which comprise the development of students' epistemological beliefs. This means relational pedagogy, which values students as knowers, experiences that relate to student's experience and constructivist approaches to teaching must also be supported by a relational curriculum that connects the content of course (structural aspects). This expected to lead to the development of relational, sophisticated epistemological beliefs, which includes the referential aspects of self and theory and structural aspects regarding the relational organization of beliefs.

\section{Rationale of the Study}

The studies discussed in the above section have acknowledged the role of epistemological teacher-beliefs (Fang, 1996; Richardson, Anders, Tidwell \& Lloyd, 1991), and also educational research as a catalyst for teaching quality and effectiveness in schools (Galton, 2000; Earl \& Katz, 2006; Earl \& Timperley, 2008; OECD, 2012). However, how far these elements affect the performance of teachers and staff in the school, in particular the aspect of teaching quality needs to be explored. Therefore, a justifiable need was felt to conduct a separate study on the role of epistemology and teacher belief towards educational research. The results of the study would be useful for administrators, school leaders, teachers and stakeholders in order to ensuring the excellence of education can be achieved successfully. 


\section{Research Questions}

The following research questions were raised to guide the conduct of the study;

1. What is the level of epistemological teacher-beliefs in educational research?

2. Is there any significant relationship between epistemological teacher-beliefs and educational research practice?

3. Does epistemological teacher-beliefs contribute to educational research practice?

4. What are the factors that contribute to the epistemological teacher-beliefs in the practice of educational research?

\section{METHOD}

\section{Research Design}

This study combines both quantitative and qualitative approaches (mixed method approach). The mixed method approach is chosen because the combination of these two methods is very relevant where it helps to complement each other's data from one source to another (Cresswell, 2007). The use of various methods for data acquisition is also known as triangulation. This method is meaningful because each method has its own advantages and disadvantages (Patton, 2002). The quantitative approach using questionnaires is used to obtain information on facts, beliefs, feelings, wants and so forth and is easy to be prepared. It is also useful to improve the accuracy of statistical analysis (Hair et al., 2006).

Meanwhile, the qualitative approach uses semi-structured interview approach. This method is performed because interviews are seen as the best techniques that can be used to carry out intensive case studies for selected individuals (Merriam, 2001). The interview not only can measure the accuracy of the obtained results of the qualitative part, but also can reveal those issues that might not be well-captured by the questionnaires (Mackey \& Gass, 2016). Before an interview began, the interviewee was informed about the research topic and he/she was assured that his or her responses to the interview questions would remain confidential. It should be noted that the interviews were run in Persian so that the teachers could express their ideas with greater ease. The participants' responses were carefully recorded by a voice recorder to be meticulously analysed and transcribed later. That is, the transcripts were independently read some times so that the researchers could make sense of them and extract the main themes.

\section{Population and Sampling}

The population of the study comprised all secondary schools teachers in the east of Peninsular Malaysia. The schools involved are selected based on simple random sampling. This simple random sampling is chosen because it is suitable when the population has a nearly uniform nature. This sampling is to get the following two things; each member of the population has the same opportunity to be elected and the selection of one subject is independent and independent of the selection of other subjects (Azizi, Shahrin, Jamaludin, Yusof \& Abd.Rahim, 2009). The basis for determining the total sample of this study is based on the Table Krejcie and Morgan (1970) that have 
determined the number of samples based on the total population. A total of 500 teachers were selected to answer questionnaire questions, while 10 teachers were chosen for interviews. The participants were selected using random sampling among the participants who fill out the questionnaires.

\section{Data Collection Tools Analysis}

This study employed a standard questionnaire which consists of three (3) parts, namely A, B, and C. Part A contains the respondents' background, Part B contains relevant items on Teachers' Perception towards Epistemology (Knowledge) and part C contains items related to Teachers' Perception towards Educational Research. In this study, a questionnaire on Teachers' Perception towards Epistemology (Knowledge) was adapted from Hofer \& Pintrich (2002), and to measure Teachers' Perception towards Educational Research, researchers have adapted the questionnaires from Broekkamp \& Van Hout-Wolters (2007).

All the instruments conform to the theory of teacher-beliefs and educational research besides following the principles of building items in terms of validity and consistency. The internal consistency of these two instruments is estimated by calculating the reliability coefficient, $\alpha$. The result of the reliability analysis for these instruments demonstrated very high reliability. The Cronbach alpha value for each instrument is between 0.84 and 0.96 . The scores for these two instruments have a very good reliability coefficient of more than 0.80 (Ary, Jacobs \& Razavieh, 2002). The measurement for each variable is to use a five-point scale.

\section{Data Analysis Techniques}

Since the current study gathered both qualitative and quantitative data, the analysis processes were also governed by the two approaches. In the quantitative section, in order to provide answers to the first three research questions, common descriptive statistics as well as the inferential statistical methods, including Pearson correlation and multiple regression analysis were run using SPSS version 24. Regarding the qualitative data, the perception teachers' accounts were used to form patterns and categorize the major themes (Strauss \& Corbin, 1998). The current study, in fact, employed content analysis to analyse the qualitative data gathered through semi-structured interviews. To this aim, the content of the interviews was examined carefully and themes were identified and presented.

\section{FINDINGS}

\section{Profile of the Respondents}

Table 1 indicates the respondents' profile by gender, age and field of teaching. The findings show that the respondents comprised 320 (64.00\%) female and $180(36.00 \%)$ male teachers with the age ranged between 20 to 59 years old. The majority came from over 40 years old age groups. In terms of field of teaching, there were $196(39.20 \%)$ teach Science \& Mathematics, Language, 94 (18.80\%) Social Science/Humanities, 162 $(32.40 \%)$ and $48(9.60 \%)$ for Technical \& Vocational. 
Table 1

Respondents by Gender, Age and Field of Teaching $(\mathrm{N}=500)$

\begin{tabular}{llll}
\hline Demographic Information & Categories & $N$ & $\%$ \\
\hline Gender & Male & 180 & 36.00 \\
Age & Female & 320 & 64.00 \\
& $50-59$ & 78 & 15.60 \\
& $40-49$ & 281 & 56.20 \\
Field of Teaching & $30-39$ & 106 & 21.20 \\
& $20-29$ & 35 & 7.00 \\
& Science \& Mathematics & 196 & 39.20 \\
& Language & 94 & 18.80 \\
& Social Science/Humanities & 162 & 32.40 \\
& Technical \& Vocational & 48 & 9.60
\end{tabular}

Research Questions 1: What is the level of epistemological teacher-beliefs towards educational research?

Descriptive statistical analysis showed that the mean score for the epistemological teacher-beliefs level towards educational research was at a moderate level $(M=3.18$, $\mathrm{SD}=0.49)$. This analysis also shows the level of epistemological teacher-belief for male teachers is higher $(\mathrm{M}=3.27, \mathrm{SD}=0.53)$ compared to the epistemological teacherbeliefs for female teachers $(\mathrm{M}=3.10, \mathrm{SD}=0.45)$, although both were at the same moderate level, as shown in Table 2.

Table 2

Mean and Standard Deviation for Epistemological Teacher-beliefs towards Educational Research $(\mathrm{N}=500)$

\begin{tabular}{lccc}
\hline \multicolumn{1}{c}{ Gender } & $\mathrm{N}$ & Mean $(\mathrm{M})$ & Std. Deviation (SD) \\
\hline Male & 180 & 3.27 & 0.53 \\
Female & 320 & 3.10 & 0.45 \\
Total & 500 & 3.18 & 0.49 \\
\hline
\end{tabular}

Research Questions 2: $\quad$ Is there a significant relationship between epistemological teacher-beliefs and educational research practice?

The analysis using Pearson correlation coefficient found that the correlation between epistemological teacher-beliefs and educational research practice has weak positive relationship but significant $(r=.26, p=.00)$ as stated in Table 3 .

Table 3

Correlation between Epistemological Teacher-Beliefs and Educational Research Practice

\begin{tabular}{lll}
\hline & epistemological teacher-beliefs & educational research practice \\
\hline epistemological teacher-beliefs & - & $.26^{* * *}$ \\
educational research practice & $.26^{* *}$ & - \\
$\mathrm{N}$ & 500 & 500 \\
\hline ***arrelation is significant at confidence level 0.01 &
\end{tabular}

Research Questions 3: Does epistemological teacher-beliefs contribute to educational research practice? 
The results of the multiple Stepwise regression analysis on the epistemological teacher belief towards the educational research in the classroom indicate that it was significant, as shown in Table 4. Analysis showed that the correlation between the epistemological teacher-beliefs and education research was .26, while the R2 value was .07 with modified R2 was .07 indicates that $7 \%$ of educational research variance can be explained by the variable of the epistemological teacher-beliefs. Statistical results also showed that the value of $F$ was 36.67 and it is significant $(p<.05)$. This finding shows that the regression model of epistemological teacher belief is significant and applicable to explain the variance of teacher's belief in educational research.

Table 4

Multiple Regression Analysis of Epistemological Teacher Belief towards Educational Research

\begin{tabular}{llllllll}
\hline Independent Variables & $\mathrm{R}$ & $\mathrm{R}^{2}$ & $\begin{array}{l}\text { Modified } \\
\mathrm{R}^{2}\end{array}$ & $\mathrm{~F}$ & $\mathrm{p}$ & $\begin{array}{l}\text { Non- } \\
\text { standard Beta }\end{array}$ & $\begin{array}{l}\text { Standar } \\
\mathrm{d} \text { Beta }\end{array}$ \\
\hline Epistemological Teacher Belief & .26 & .07 & .07 & 36.67 & .00 & .61 & .26 \\
\hline
\end{tabular}

Table 5 further demonstrates that significant predictor variables, that is, epistemological teacher-beliefs $(\beta=.26, p<.05)$ is a factor in the practice of educational research in the classroom. The results of the analysis showed significantly that the epistemological teacher-beliefs contributed $7 \%(\mathrm{R} 2=.07)$ variance change to educational research $[\mathrm{F}(1$, 498) $=36.67, \mathrm{p}<.05]$.

Table 5

Multiple Regression Analysis Variable Epistemological Teacher-Beliefs on Educational Research

\begin{tabular}{llllll}
\hline \multirow{2}{*}{ Independent Variables } & \multicolumn{5}{l}{ Dependent Variable (Educational Research) } \\
\cline { 2 - 6 } & $\begin{array}{l}\text { Non- standard } \\
\text { Beta }\end{array}$ & $\begin{array}{l}\text { Non-standard } \\
\text { Error }\end{array}$ & $\begin{array}{l}\text { Standard } \\
\text { Beta }\end{array}$ & t & \multicolumn{2}{c}{$\mathrm{p}$} \\
\hline Constant & 45.99 & 8.86 & & 5.19 & $.00^{*}$ \\
$\begin{array}{l}\text { Epistemological teacher } \\
\text { belief }\end{array}$ & .61 & .10 & .26 & 6.06 & $.00^{*}$ \\
F Value & 36.67 & & & & $.00^{*}$ \\
\hline
\end{tabular}

$* \mathrm{p}<.05$

Based on the above regression analysis results, the epistemological teacher belief is a factor in the practice of teacher education research. Because the predictor variables show the significance of teachers' trust in education research, the model of regression equation that is appropriate to be used to predict teachers' trust in education research is:

Educational Research $=45.99+.61$ (epistemological teacher belief) $+e(6.06)^{*}$

$* \mathrm{p}<.05, \mathrm{R}^{2}=7 \%$

Research Questions 4: What are the factors that contribute to the epistemological teacher-beliefs in the practice of educational research?

In response to this question, because of space limitation, the words of two participants will be presented. For example, one female teacher commented that: 
"We have to understand exactly what education research is. Educational research is used to solve social problems or organizations or phenomena in a short time. It aims to improve the quality of a practice ... the practice of teacher teaching in the classroom... "

The researchers then asked the respondents to clarify the meaning of improving the quality of teacher's teaching practice through educational research. Then she responds;

"Researchers can improve the quality of professionalism and change teachers' teaching practices in a better way by investigating social situations in educational organizations. Research conducted can provide guidance, make corrections and evaluate decisions and actions taken ".

One male teacher in a state school remarked that:

"To change a practice, there needs to be a catalyst that can trick or distract teachers. Here is a need for school administrators to inculcate a research culture at school, stimulating teachers to conduct research to improve teaching practices in a better direction ..."

In summary, interviews show that there are two main elements that contribute to the epistemological teacher-beliefs in educational research, which is the understanding of teachers on educational research and the support of school administrators to create educational research culture at school.

\section{DISCUSSION AND CONCLUSION}

The findings show that the level of epistemological teacher-beliefs towards education research among teachers is at a moderate level, which is still at a less satisfactory level. Among the factors that led to this scenario was due to the fact that teachers still did not clearly understand the concept of epistemological teacher beliefs on educational research. The findings of this study are also parallel and consistent with the Brownlee (2003, 2001) and Entwistle, Skinner, Entwistle \& Orr (2000) which described links between epistemological beliefs, and beliefs about teaching and learning. Teaching, as well as learning, may also be influenced by epistemological beliefs. This means that individuals with relativistic epistemological beliefs are more likely to conceive of teaching as a process of facilitation rather than one based only transmission of knowledge.

The fundamental beliefs of teachers on education research can change their teaching practices in a better direction should be further enhanced. They must believe that the quality of their teaching can be enhanced by the practice of educational research made because of these practices they can identify the teaching methods that emphasize the skills and capabilities of the students, considering the diversity that exists between the students and making a systematic and competitive teaching assessment. With that, the quality of their teaching can be enhanced.

The combination of both quantitative and qualitative findings shows that the practice of educational research among teachers is influenced by the epistemological teacher belief. These findings support the theory of learning by Brownlee, Joanne (2004) which highlighted 3 "P" as the basis for a quality teaching process, namely presage, process and product (Biggs, 1993). Teachers should implement research practices to identify 
what future needs, skills and competencies required by students in the face of rapidly changing world. Thus, teachers should provide the best quality and best teaching services to students as a platform for them to acquire the necessary skills in preparation for the challenges of learning new millennium. This is because teachers' perceptions and beliefs are very significant contributors to individual change (Smylie, 1988). With this in mind, a growing body of research is indicating that teacher educators need to focus on teacher beliefs as a way to facilitate effective learning in tertiary education (Fang, 1996; Richardson, Anders, Tidwell \& Lloyd, 1991) and may provide valuable insights into how to improve teaching and learning in higher education (Beers, 1984; Hofer, 1994; Hofer \& Pintrich, 1997; Schommer, 1990, 1993a, 1993b).

Quality teachers are teachers who can deliver excellent teaching practices in the classroom and produce the best student achievement output. An excellent teaching practice is the teaching process conducted in the classroom by taking into account the diversity of potential students, the use of multiple teaching aids that can attract students and thus ensure the objective of teaching can be achieved successfully. For that purpose, teachers should conduct educational research to identify what efforts need to be taken and actions to be taken to ensure the learning and teaching process in the classroom can be successfully implemented (Sammons, 2012; Cordingley and Mitchell, 2013; Earl \& Timperley, 2008; Earl \& Katz, 2006).

In line with the current study, some recommendations for further research are offered. It is recommended that longitudinal research should be carried out to "see whether the type of school category, whether high, medium and low achievement school, affects the level of epistemological teacher belief among teachers". More studies can also explore the correlation between job satisfaction and job performance among teachers. In the end, further research can be run to identify what types of school climates will ease the epistemological teacher confidence level towards educational research among teachers, in an effort to uphold the educational research culture among teachers.

\section{Acknowledgement}

This research was funded by International Matching Grant between Malaysia-Indonesia (UUM-UHAMKA). Hence, the highest appreciation and acknowledgement is addressed to UUM, UHAMKA, Research and Innovation Management Centre (RIMC), UUM, IETLE, SEML, UUM and LITBANG, UHAMKA.

\section{REFERENCES}

Ary, D., Jacobs, L. C., \& Razavieh, A. (2002). Introduction to research in education. Sixth Edition. USA: Wadsworth Group.

Azizi, Y., Shahrin, H., Jamaludin, R., Yusof, B., \& Abdul, R. H. (2009). Mastering research in education. BS Print (M) Sdn. Bhd.

Beers, S. E. (1984, March). An analysis of the interaction between students' epistemological assumptions and the composing process. Paper presented at the Annual Meeting of the Conference on College Composition and Communication, 35th, New York City. 
Beycioglu, K., \& Ozer, N. (2008, September). Teachers' views on education research. Poster presented at the European Education Research Association Conference, Göteborg, Sweden.

Biggs, J. (1993). What do inventories of students' learning process really measure? A theoretical review and clarification. British Journal of Educational Psychology, 83, 3-19. doi:10.1111/j.2044-8279.1993.tb01038.x.

British Educational Research Association, BERA. (2014). The role of research in teacher education: Reviewing the evidence. Interim Report of the BERA-RSA Inquiry.

Broekkamp, H., \& van Hout-Wolters, B. (2007). The gap between educational research and practice: A literature review, symposium, and questionnaire. Educational Research and Evaluation, 13(3), 203-220. https://doi.org/10.1080/13803610701626127.

Bronkhorst, L., Meijer, P. C., Koster, B., \& Vermunt, J. D. H. M. (2011, April). Collaboration as means to promote research use. Paper presented at the annual conference of the American Educational Research Association, New Orleans, LA.

Brownlee, J. (2001). Epistemological beliefs in pre-service teacher education students. Higher Education Research \& development, 20, 3, 281-291.

Brownlee, J. M. (2003). Paradigm shifts in preservice teacher education students: A case study of Changes in epistemological beliefs for two teacher education students. Australian Journal of Educational \& Developmental Psychology, 1, 3.

Brownlee, J. (2004). An investigation of teacher education students' epistemological beliefs: Developing a relational model of teaching. Research in Education 72, 1-18.

Cooper, A. (2010, May). Knowledge brokers: A promising knowledge mobilization strategy to increase research use in education. Paper presented at the annual conference of the American Educational Research Association, Denver, CO.

Cordingley, P. (2009, March). Using research and evidence as a lever for change at classroom level. Paper presented at the annual conference of the American Educational Research Association, San Diego, CA.

Cordingley, P. (2013) The contribution of research to teachers' continuing professional learning and development. London: BERA.

Creswell, J. W. (2007). Qualitative inquiry and research design: Choosing among five traditions. Thousand Oaks, CA: Sage.

Earl, L., \& Katz, S. (2006). Leading in a data rich work. Thousand Oaks, CA: Corwin Press.

Earl, M. L., \& Timperley, H. (2008). Learning from the QT R\&D programme: Findings of the external evaluation, Oct 2008.

Entwistle, N., Skinner, D., Entwistle, D., \& Orr, S. (2000). Conceptions and beliefs about "good teaching": An integration of contrasting research areas. Higher Education Research \& development, 19(1), 5-26.

Everton, T., Galton, M., \& Pell, T. (2000). Teachers' perspectives on educational research: Knowledge and context. Journal of Education for Teaching, 26(2), 167-182. 
Fang, Z. (1996). A review of research on teacher beliefs and practices. Educational Researcher, 38, 49-65.

Galton M. (2000, November). Integrating theory and practice: Teachers' perspectives on educational research. Paper presented at the ESRC Teaching and Learning Research Programme, First Annual Conference - University of Leicester, Leicester.

Groth, R. E., \& Bergner, J. A. (2007). Teachers' perspectives on mathematics education research reports. Teaching and Teacher Education, 23(6), 809-825. https://doi.org/10.1016/j.tate.2005.12.002

Gunstone, R. (1989, March). Learning about learning to teach: A case study of pre-service teacher education. Paper presented at the meeting of the American Educational Research Association, San Francisco.

Hair, J. F., Black, W. C., Anderson, R. E., \& Tatham, R. L. (2006). Multivariate data analysis. Sixth Edition. Pearson International Edition.

Hargreaves, D. (1996) Teaching as a research-based profession: possibilities and prospects, Teacher Training Agency 1996 Annual Lecture, London: TTA.

Hemsley-Brown, J., \& Sharp, C. (2003) The use of research to improve professional practice: A systematic review of the literature. Oxford Review of Education, 29(4), 449-470. Retrieved March 2, 2012, from http://epubs.surrey.ac.uk/479/1/fulltext.pdf

Hofer, B.K., \& Pintrich, P. R. (2002). Personel epistemology: The psychology of beliefs about knowledge and knowing. Mahwah, New Jersey: Lawrence Erlbaum Associates, Inc.

Hofer, B., \& Pintrich, P. (1997) The development of epistemological theories: Beliefs about knowledge and knowing and their relation to learning. Review of Educational Research, 67(1), 88-140.

Joram, E. \& Gabriele, A. (1998). Preservice teacher's prior beliefs: transforming obstacles into opportunities. Teaching and Teacher Education, 14(2), 175-191.

Lysenko, L., Abrami, P. C., \& Bernard, R. M. (2011, April). Researching research use: An online study of school practitioners in Canada: Quantitative results. Paper presented at the annual conference of the American Educational Research Association, New Orleans, LA.

Marso, R. N., \& Pigge, F. L. (1989). The influence of preservice training and teaching experience upon attitude and concerns about teaching. Teaching and Teacher Education, $5(1), 33-41$

McLean, V. S. (1999). Article 1, Chapter 2. In Richard Lipka \& Thomas Brinthaupt (Eds.), The Role of Self in Teacher Development . Albany: State University of New York Press.

Merriam, S. B. (2001). Qualitative research \& case study applications in education. San Francisco: Jossey-Bass Pub.

Mertz, N. T., \& McNeely, S. R. (1991, April). Cognitive constructs of pre-service teachers: How students think about teaching before formal preparation. Paper presented at the annual meeting of the American Educational Research Association, Chicago, IL. 
Morales, M. P. E., Abulon, E. L. R., Soriano, P. R., David, A. P., Hermosisima, M. V. C., \& Gerundio, M. G. (2016). Examining teachers' conception of and needs on action research. Issues in Educational Research, 26(3), 464-489.

OECD (2012). Equity and quality in education. Supporting disadvantaged students and schools. Paris: OECD.

Pajares, M. F. (1992). Teachers' beliefs and educational research: cleaning up a messy construct. Review of Educational Research, 62(3), 307-333.

Patton, M. Q. (2002). Qualitative research and evaluation methods. Thousand Oaks: Sage Publications.

Purnomo, Y. W., Suryadi, D., \& Darwis, S. (2016). Examining pre-service elementary school teacher beliefs and instructional practices in mathematics class. International Electronic Journal of Elementary Education, 8(4), 629-642.

Perry, W. G. J. (1981). Cognitive and ethical growth: The making of meaning. In A. W. Chickering (Eds), The modern American college (pp. 76-116). San Francisco: Jossey-Boss.

Richardson, V., Anders, P., Tidwell, D., \& Lloyd, C. (1991). The relationship between teachers' beliefs and practices in reading comprehension instruction. American Educational Research Journal, 28(3), 559-586.

Schoenfeld, A. H. (2009). Instructional research and the improvement of practice. In J. D. Bransford, N. J. Vye, D. J. Stipek, L. M. Gomez, \& D. Lam (Eds), The role of research in educational improvement (pp. 161-188). Cambridge, MA: Harvard Education Press.

Schommer, M. A. (1993a). Comparisons of beliefs about the nature of knowledge and learning among postsecondary students. Research in Higher Education, 34(3), 355-370.

Schommer, M. A. (1993b). Epistemological development and academic performance among secondary schools. Journal of Educational Psychology, 85(3), 406-411.

Smylie, M. (1988). The enhancement function of staff development: Organizational and psychological antecedents to individual teacher change. American Educational Research Journal, 25(1), 1-30.

Stafford, J. T. (2006). The importance of educational research in the teaching of history. Canadian Social Studies, 40(1), Special Issue: History Alive! Old Sources, New Technologies. www.quasar.ualberta.ca/css

Strauss, A., \& Corbin, J. (1998). Basics of qualitative research: Techniques and procedures for developing grounded theory. Thousand Oaks, CA: Sage Publications.

Vanderlinde, R., \& van Braak, J. (2010). The gap between educational research and practice: views of teachers, school leaders, intermediaries and researchers. British Educational Research Journal, 36(2), 299-316. https://doi.org/10.1080/01411920902919257

Wilke, R. (2004). How content area influences choice of instructional methods: an examination of one component of preservice teacher belief (Unpublished master's thesis). The Florida State University, USA.

Whitbeck, D. A. (2000). Born to be a teacher: What am I doing in a college of education? Journal of Research in Childhood Education, 15(1), 129-36. 